open Access

Natalia Schäfer ${ }^{1}$ (D) 0000-0003-4620-292X

Radostaw Balwierz ${ }^{1}$ (D) 0000-0002-6173-2702

Anna Krzeszewska-Zaręba ${ }^{2}$ (D) 0000-0003-2036-6061

Zbigniew Skotnicki ${ }^{3}$ (D) 0000-0001-6039-0950

Urszula Skotnicka-Graca ${ }^{3}$ (D) 0000-0001-5554-0184

Kornelia Kalarus ${ }^{2}$ (D) 0000-0002-6615-4606

${ }^{1}$ Department of Pharmacy and Ecological Chemistry, Faculty of Chemistry, University of Opole, Oleska Street 48, 45-052 Opole

C+48774527113凶radoslaw.balwierz@uni.opole.pl

2 Department of Health Protection, Medical University of Silesia in Katowice, Mickiewicza Street 29, 40-085 Katowice

${ }^{3}$ Library of the University of Opole, Strzelców Bytomskich Street 2, 45-052 Opole

Cite / Sposób cytowania Schäfer N, Balwierz R, Krzeszewska-Zaręba A, et al. The use of botanical raw materials in hair dyeing. Aesth Cosmetol Med. 2021;10(6):263-269. https://doi.org./10.52336/acm.2021.10.6.01

\title{
The use of botanical raw materials in hair dyeing
}

\section{Zastosowanie surowców roślinnych w koloryzacji włosów}

\begin{abstract}
The cosmetic market is rich in products that allow changing the color of hair. There are three options for chemical coloring, depending on the duration of the target color. Among them, there are short-term, semi-permanent, and long-term dyeing. Using synthetic ingredients, it is possible to obtain a full range of colors. Reports of undesirable side effects of chemical dyes on both the scalp and hair structure support a return to natural hair coloration and a development in this direction.

The aim of the work was to draw attention to apply botanical raw materials in hair dyeing.

The work presents the characteristics of the following plant materials used in hair dyeing: defenseless lawsonia, oxalic hibiscus, rhubarb, elderberry and chamomile.
\end{abstract}

Keywords: hair dye, synthetic dyes, natural pigments, botanical raw materials

\section{STRESZCZENIE}

Rynek kosmetyczny bogaty jest w produkty umożliwiające zmianę koloru włosów. Dostępne są trzy możliwości koloryzacji chemicznej zależne od czasu utrzymywania się docelowego koloru. Wśród nich wyróżnia się farbowanie krótkotrwałe, półtrwałe oraz długotrwałe. Przy użyciu składników syntetycznych możliwe jest uzyskanie pełnego przekroju kolorystycznego. Doniesienia o niepożądanych skutkach ubocznych farb chemicznych, zarówno dotyczących skóry głowy jak i struktury włosów przemawiają za powrotem naturalnych sposobów koloryzacji włosów, i za rozwojem tego kierunku.

Celem opracowania było przybliżenie możliwości zastosowania surowców roślinnych celem koloryzacji włosów.

Scharakteryzowano następujące surowce roślinne wykorzystywane w farbowaniu włosów: lawsonia bezbronna, ketmia szczawiowa, rzewień, bez czarny oraz rumianek pospolity.

Słowa kluczowe: farbowanie włosów, syntetyczne barwniki, naturalne pigmenty, surowce roślinne

\section{INTRODUCTION}

Hair plays a significant role in body image and its appearance can be relatively easily changed without the use of very invasive treatments. This is a reason why cosmetic products and techniques have been used to change the appearance of the hair since always. The cosmetics industry developed effective products that can be applied to healthy hair, as well as in the case of hair and / or scalp diseases [1]. One of the first cosmetics created to nourish and change the the hair colour were based on natural substances. The first reports of these kinds of formulations date back to ancient Egypt. Over the centuries, many different ways were used to modify hair colour, and this process was accompanied by ever-changing fashion [2]. 


\section{HAIR CONSTRUCTION AND STRUCTURE}

The hair is a callous, smooth formation made of epidermal cells, present almost on the entire surface of the body, excluding the soles of the feet, hands, red lips and mucous membranes. Each hair consists of two parts, the first one is above the skin and it is the shaft, the second one below is the hair root [3]. The shaft is the stem of the hair. It is a dead part composed of three layers: the inner layer - cortex (cortex), the core layer (medulla) and the surrounding layer, i.e. the outer layer, the so-called casings (cuticula). The cuticle is made up of 5-10 layers of flat, nuclear-free cells arranged in a characteristic overlapping pattern, with only one-sixth of each surface exposed. It is the least sensitive part of the hair to external factors, due to the presence of as much as $30 \%$ of cystine. The mentioned amino acid is created by connecting two cysteine particles with a disulphide bond. Formed in this way microscopic keratin chains are this solution that guarantees high resistance of hairs. The cortex forms about $80-90 \%$ of the entire hair shaft, making it the largest part. Its diameter may vary, depending on ethnicity, from 40 to $100 \mu \mathrm{m}$. The protein that makes up the hair structure is also keratin, in which molecules form chains, and then they merge into fibers. These formations of keratin are called microfibrils and fibrils. The keratin cells within the root contain a nucleus, are spindle-shaped, about 100 microns long, and arranged longitudinally. Inside the hair, there is cellular cement responsible for protection against excessive water loss, as well as dye grains. Below the sheath is the aforementioned hair core. Its presence can be observed only in thick hair, while in the case of thinner hair, there is an empty space at the core. The inside of the core is a spongy mass, composed of 1-2 rows of transversely flattened cells, containing small amounts of dye grains and hydrophilic components. The discussed structure is responsible for the very high resistance of the hair, including the stretching. The surface of the hair has a pH ranging from 4.5 to 5.5 [4].

Below the skin is a hair root, placed in an epithelial sac called a hair follicle. There are about 120,000 hair follicles in the scalp. This number is determined genetically and remains the same until the end of life. Expanding downwards, the root forms the hair bulb. It is made of living cells - keratinocytes that produce keratin. The keratinization cycle takes place between the bulb and the opening of the sebaceous gland. The hair root is not perpendicular to the skin, but is stuck in it obliquely, therefore the hair has the ability to arrange itself into strands. The paranasal muscle with the sebaceous glands adjoins directly to the hair root. They have a line leading to the hair follicle near the epidermis through which their secretion, i.e. sebum, is distributed. Below the hair root there is its bulb, and they all are surrounded by an inner and outer sheath. At the bottom of the hair follicle there is a hair papilla which is supplied with nutrients by blood from capillaries. Above the hair nipple, within the ma- trix, there is a cluster of melanocytes responsible for the colour of the hair. Hair colour mainly depends on the quantity, quality and distribution of the melanin pigment. Its content is largely determined by genetic predisposition. This dye comes in two varieties: pheomelanin and eumelanin. The first one determines the yellow-red colour, while the second one is brown to black. Melanosomes are more densely distributed in the outer layers of the cortex than in the central core $[5,6]$. Over time, melanocytes begin to produce much fewer melanosomes, so the hair loses its previous colour and becomes silvery white without dye. In the case of albinos, melanocytes do not produce pigment. In addition, melanins play an important role, among others in the protection of individual strands of hair against ultraviolet radiation [7, 8].

\section{HAIR CHEMICAL COMPOSITION}

The largest component of the hair is an insoluble protein substance, which is keratin, and a few water-soluble ingredients. Like other proteins, keratin is made up of amino acids. Hair is made up of 25 different types of these molecules, 18 of which are found in keratin. In addition to the above, hair also consists of some elements. The chemical structure of hair includes: carbon, nitrogen, hydrogen, oxygen, sulphur, chlorine and phosphorus, as well as trace amounts of calcium, iron, zinc, copper and manganese. Sulphur is especially important due to its presence in molecules of keratin protein. Moreover, healthy hair consists of water (approx. $10-15 \%$ ), as well as pigments and lipids (less than 15\%). The chemical composition of hair does not change depending on gender or ethnic origin [7, 9].

Hair-building keratin comes in two forms: fibrous and amorphous keratin. The first one is the mass of the cortex, while the second forms the intercellular binding material that fills the defects in the hair shaft and cuticles. Thanks to this, the structure of the hair is sealed, and the hair itself retains its elasticity.

The keratin in the hair is represented as the structure of the helix within which there are bonds that connect its chains. These are:

- peptide bonds - are the connection between the amino acids that make up the protein and between the adjacent keratin chains;

- hydrogen bonds - formed between oxygen atoms of carboxyl groups and hydrogen atoms of amino groups, they are sensitive to the action of water;

- ionic bonds - formed by transferring the hydrogen atom from the carboxyl group - $\mathrm{COOH}$ to the nitrogen atom of the amino group - NH2, they are also sensitive to the action of water, as well as electrolytes, reducing agents, oxidants and changes in $\mathrm{pH}$;

- disulphide bonds - they are the strongest and structurally the most important bond that keeps keratin proteins together, giving shape to the hair $[7,8,10]$. 


\section{COMPARISON OF CHEMICAL AND NATURAL COLOURS}

\section{Chemical colouring}

The first synthetic and, importantly, harmless to health, hair dye was created in France in 1907. It was characterized by the possibility of obtaining a long-lasting blonde colour, which was extremely desirable at that time. This discovery initiated the dynamic development of hairdressing, which is noticeable until today due to the availability of dyes in almost every colour. The development of this trend proves the great success of these cosmetics [2].

The natural colour of hair can be changed synthetically in three ways. By using temporary colouring, semi-permanent or direct colouring, and also by using permanent colouring (Table 1).

Table 1 Available types of synthetic dyes and their characteristics

\begin{tabular}{|c|l|l|l|}
\hline Lp. & Dyeing type & \multicolumn{1}{|c|}{ Durability } & \multicolumn{1}{c|}{ Colouring component } \\
\hline 1. & Temporary & $\begin{array}{l}\text { to the first } \\
\text { wash }\end{array}$ & $\begin{array}{l}\text { brilliant blue, disazo brown, } \\
\text { xanthene red, azo red, fluore- } \\
\text { scein, anthraquinone green }\end{array}$ \\
\hline $\begin{array}{l}\text { Semi- } \\
\text {-permanent }\end{array}$ & to 6-8 washes & $\begin{array}{l}\text { nitrophenyldiamines, nitro- } \\
\text { aminophenols and compo- } \\
\text { unds from the group of amino } \\
\text { anthroquinones }\end{array}$ \\
\hline 3. & $\begin{array}{l}\text { Permanent } \\
\text { is forced by } \\
\text { hair growth }\end{array}$ & $\begin{array}{l}\text { above colouring components } \\
\text { included in semi-permanent } \\
\text { mixtures, as well as direct } \\
\text { dyes, oxidant, alkalizing com- } \\
\text { pound, antioxidants, and } \\
\text { compounds reducing the ef- } \\
\text { fect of colour discolouration } \\
\text { under the influence of UV }\end{array}$ \\
\hline
\end{tabular}

Source: $[7,19]$

The first type - temporary colouring- is characterized by a rapid loss of colour, which occurs after the first washing. This is due to the low absorption of the dye on the hair surface, without penetrating into the hair. The low bond strength between the hair and the dye can be easily broken during the first washing with water solutions of surfactants, i.e. a classic shampoo. The second type - semi-permanent (semi-permanent) - is characterized by relatively slow rinsing off the dye, even up to 6-8 washes. Initially, this type of hair dyeing was used to colour gray hair, but for a long time this method has also been used for hair of a different colour. Dye diffusion into the hair structure is weak, but stronger than in the case of the short-term dyeing. In hairdressing salons, there is an additional type of hair dyeing that gains more and more attention. It is an intermediate dyeing, between semi-permanent and permanent, the so-called demi-permanent. It combines the features of semi-permanent dyes with oxidative dye precursors and diluted hy- drogen peroxide, creating a system with increased pigment stability in the hair. The most durable method of colouring the hair is based on the permanent (oxidative) application of the dye, where the colour change persists even after repeated use of the cleanser, until re-use due to new hair growth, the so-called regrowth. This type of dyeing allows to obtain any shade and at the same time lighten or cover gray hair. In contrast to semi-permanent dyeing, here the process takes place in a fully alkaline environment. Under these conditions, the hair swells and the main pigment component reaches the inside of the hair. The dyes compounds used are colourless dye precursors which react with each other in the presence of oxidants to form highly-molecular colour associations. The oxidant may be hydrogen peroxide, less commonly urea or melanin peroxide, and sodium perborate. Ammonia is usually used as the alkalizing compound, but due to its unpleasant odour, manufacturers replace it with amino acids, alkanolamines or ammonium carbonate. The use of any of the aforementioned oxidants to obtain the colour also allows the natural pigment to be bleached one or two shades at the same time as the synthetic colour is formed. The mixture of dyes also includes antioxidants (glycolic acid, ascorbic acid, phenylmethylpyrazolone) and compounds reducing the effect of discolouration under the influence of sunlight. In addition, despite dyes, in preparations characterized by the possibility of obtaining a permanent colour, direct dyes are also used, most often these are nitrobenzene derivatives. Their presence guarantees a range of red, mahogany and purple shades. In widely available hair dye products, the two ingredients are usually in two separate packages, often the hydrogen peroxide is in the form of a powder and the dyes are in the form of lotions, gels, shampoos or creams. Dye precursors contain two types of reagents: perfluorodecalin and aminophenol. They work by penetrating the swollen keratin fibers, where they undergo oxidation. Usually, the staining reaction time is up to 30 minutes $[7,11,12]$.

\section{SIDE EFFECTS OF CHEMICAL HAIR DYEING}

The ingredients of synthetic hair dyes are highly allergenic. Paraphenylenediamine PPD ( $p$-phenylenediamine, 4-phenylenediamine) is a highly sensitizing aromatic amine substance which the main function is to change the hair pigment. Its significant amount is found in black paints, slightly less in brown, chestnut and red. Its acceptable content in these products is from 0.2 to $4 \%$. For the determination of harmful substances in hair dyes, thin-layer chromatography is mainly used $[1,11,13]$.

In one of the studies on the hair structure, it was proved that the use of colouring preparations causes structural damage, mainly to the hair shaft. It is caused by dyes which contained in their composition p-phenylenediamine, m-aminophenol, resorcinol and hydrogen peroxide as an oxi- 
dant. Apart from the reaction inside the hair, swelling of the skin with visible erythema within the area of application was noted. In some places, the hair cortex has been exposed close to the skin surface due to extensive detachment of the epidermis. Void spaces of various sizes were formed within the endothelium, and small focal gaps formed along the extracellular space. The changes were particularly noticeable at 6 hours and 1 day after application, and then gradually improved. After eight weeks, the hair cuticle had completely regenerated and returned to its state before dyeing. It is worth adding that such treatments, chemically and physically changing the hair structure, lead to a reduction in hair elasticity, causing split ends or breaking [14].

\section{PLANT COLOURING}

An alternative to chemical hair colouring is the use of herbs. Although permanent synthetic dyes are widely available and economically beneficial, their main disadvantage is frequent allergic reactions and damage to the hair structure $[14,15]$. Botanical hair dyes are devoid of potential toxic factors for skin and body, and are often considered safer and irritation free. Although their safety largely depends on the family to which a given plant material belongs, as some of them may have allergic or irritant potential. In addition, the plant composition applied to the scalp and hair often supports the treatment of dermatological diseases (for instance dandruff), soothes inflammation, and prevents hair loss or supports its regeneration, giving the hair shine and improving its structure. An additional advantage of herbal colouring is the lack of unpleasant odour associated with the use of an oxidant, which is not required in this process, unlike chemical dyeing $[16,17]$. Currently, there is a wide spectrum of colours that can be obtained on hair with the help of many plants [18]. Natural colours are defined as chemicals obtained from plant sources without chemical processing. The natural pigment is obtained from seeds, flowers, leaves, fruits, stems, bark and roots of plants. Some of those mentioned may have more than one colour depending on the part of the plant used. The colour tone produced may vary depending on the harvest season, cultivation method and soil conditions. It is worth adding that there are about 300 species of plants from which pigments are extracted $[19,20]$. Natural dyes represent a wide range of organic groups with different chemical structures (Table 2) [19, 20].

The dyeing process based on plant materials includes three main stages. The first step is the extraction of dyes from a given part of the plant. Next, there is formation of a bond between the dye and the fiber to be dyed. The final phase is the actual dyeing. Colour extraction is usually done by pulverizing the material and then boiling it in water for 10-20 minutes. The method of obtaining a dye from plant material is environmentally friendly, because only water, usually demineralized, is used for extraction. This type of

Tabela 2 Powszechne barwniki naturalne
\begin{tabular}{|l|l|l|}
\hline \multicolumn{1}{|c|}{ Chemical group } & \multicolumn{1}{|c|}{ An example of occurrence } & \multicolumn{1}{c|}{ Dye } \\
\hline indigoids & $\begin{array}{l}\text { indigo barberry } \\
\text { (Indigofera tinctoria L.) }\end{array}$ & navy \\
\hline anthraquinones & $\begin{array}{l}\text { rose madder } \\
\text { (Rubia tinctorum L.) }\end{array}$ & red \\
\hline naphthoquinones & $\begin{array}{l}\text { lawsonia defenseless, henna } \\
\text { (Lawsonia inermis) }\end{array}$ & orange, brown \\
\hline flavones & dahlia (Dahlia) & yellow, brown \\
\hline anthocyanins & $\begin{array}{l}\text { grapevine proper } \\
\text { (Vitis vinifera L.) }\end{array}$ & red-orange \\
\hline betalains & carnation (Dianthus) & red \\
\hline carotenoids & arnota proper (Bixa orellana L.) & red-blue \\
\hline ferulic acid & turmeric (Curcuma longa) & yellow-orange \\
\hline alkaloids & barberry (Berberis) & yellow-orange \\
\hline chlorophyll & alfalfa (Medicago sativa L.) & yellow \\
\hline
\end{tabular}

Source: $[19,20]$

extract prevents the accumulation of minerals on the surface of the hair, which makes it difficult for the dye to bind with keratin. In order to colour the hair, herbs are most often used in the form of powders, water extracts or seed oils and oily macerates [16, 19, 21].

In a microscopic study carried out in one of the experiments related to the use of plant colouring on gray hair, devoid of natural pigment, it was proved that the herbal pigment penetrates deeply into the core area without damaging the hair cortex [17].

\section{CHARACTERISTICS OF SELECTED PLANT RAW MATERIALS USED IN THE COLOURING}

Lawsonia defenseless, also known as henna or mhendi (Lawsonia inermis L.), comes from the Lythraceae family. It occurs in tropical and subtropical areas, and is cultivated on an industrial scale in India, Iran, Pakistan, Egypt, Sudan, and also in Australia. The defenseless lawsonia is a twoyear-old shrub or small tree, measuring from 2 to 6 meters in height $[22,23]$.

The leaves of the plant contain a characteristic colouring compound - lawson (2-hydroxy-1: 4 naphthoquinone), which average content is close to $1 \%$. The other ingredients are: luteolin, gallic acid, glucose, mannitol, fats, gum (2\%), mucus and trace amounts of other alkaloids. The flowers provide essential oil (0.01-0.02\%) that is brown or dark brown and has a strong smell. The seeds contain proteins $(5.0 \%)$, carbohydrates (33.62\%), fiber (33.5\%), fatty oil (10-11\%), and the root has a red colour. Lawson, as a molecule, has an affinity for the protein found in the hair and skin - keratin, and binds to form a permanent complex. As a result, it is used to dye skin, hair, nails, animal skin, silk 
and wool. Quantitative analysis of the lawson extracts obtained from lawsonia leaves can be performed using chromatographic techniques. Such studies indicate high variability of the dye content in commercial plant products [16, 21-23]. Lawson is extracted from the leaves by hot water extraction. To prepare a paste, the so-called henna, the powdered leaves are mixed with a mildly acidic ingredient, for instance lemon juice, because the highest uptake of both henna extracts and the lawson itself was noted at a pH of 3 . The mixture thus prepared, while still warm, is set aside, for a few hours to release the dye, then applied to the hair or skin. During colourization, which lasts from one to three hours, the hair should be covered with a scarf or a shower cap to keep it warm and avoid drying out. Depending on the conditions used, like the $\mathrm{pH}$ of the paste, the temperature and the colour of the dyed hair, obtained shades are reddish to brown. Using this traditional method, besides the lawson, other ingredients are extracted from henna that affect the final shade of the hair or skin. It is worth adding that due to its low toxic potential, there is a growing interest in the defenseless lawsona itself as a dye in commercial hair dye products [21].

Hibiscus (Hibiscus sabdariffa L.) from the Malvaceae family comes from Asia (from India to Malaysia) or from tropical Africa. It is commonly planted as an ornamental plant in Central America, India, Africa and Australia. It is cultivated on an industrial scale in Sudan, especially in the western part of the country. The sorrel hibiscus is an annual plant that grows over 3 meters high [24]. The raw material obtained from the plant is fleshy flower goblets (Hibisci sabdariffae flos FP XI) containing significant amounts of anthocyanin dye - hibiscin, organic acids and vitamin $\mathrm{C}$ as well as: flavonoids, polysaccharides, mainly mucilages and pectins, as well as phytosterols. The leaves are rich in proteins, fats, carbohydrates, fiber and some minerals such as iron and vitamins [25-27]. A red powder is obtained from dried and then finely ground flowers. It is used as a natural food and cosmetic dye, mainly hair dye. In one of the conducted studies, it was shown that the use of hibiscus flowers significantly reduces undesirable yellowish and orange shades on bleached hair. This means that the addition of the aforementioned ingredient significantly cools the hair colour. The colour change was obtained thanks to the use of a paste made of hibiscus petals and water. In addition to the above properties, it was already proved that it has a beneficial effect on hair growth, and even stimulates hair regrowth in people struggling with alopecia [28-30].

Rhubarb (Rheum officinale Baillon) from the family knotweed (Polygonaceae) is a plant known since antiquity. Originally it comes from India, and now is widely cultivated. The raw material used for cosmetic and therapeutic purposes are the underground parts of the plant, rhizome with the roots of the slaughtering - Rhei radix FP XI, which is also sup- plied by the palmatum (Rheum palmatum L.). The raw material contains anthraquinones (60-80\%), tannins, mainly gallic acid derivatives, naphthoquinone derivatives, starch and phytosterols. It has been proven that the paste made of the root mixed with water is effective in darkening the hair. This is probably due to the content of anthraquinones, which are extremely diverse chemical structures, more than any other group of plant pigments. Their pigments are yellow to red [31, 32].

Black elderberry, colloquially, elderberry (Sambucus $n i$ gra L.) comes from the moschatel family (Adoxaceae). This species occurs in Europe, America, North Africa and Central Asia. It is a shrub up to 4 meters high, that usually grows in humid areas, forests, thickets or riversides. The herbal raw materials are mainly dried flowers (Sambuci flos FP XI), fruits (Sambuci nigri fructus), bark (Sambuci cortex) and root (Sambuci nigri radix) [26, 33-36]. Black elderberry is mainly known for the flavonoid fraction (up to 3\%) with antioxidant properties. Their greatest concentration is present in elderberry leaves. The chemical composition also includes phenyl acids and their glycosides, sterols, cholesterol and essential oil. In the case of elderberry fruits, the main bioactive ingredients are anthocyanins. There are also organic acids, such as acetic, malic or shikimic acids, as well as vitamins such as vitamin C, group B vitamins and carbohydrates. Potentially toxic sambunigrin is found in fresh leaves and unripe fruits. Its negative impact on health is neutralized by thermal treatment [37]. The main raw material used in cosmetics and hair care, as well as in colouring is elderberry fruit. In ancient times, the Romans used elderberry to dye their hair. One historical review found information about the use of plant sap to colour white napkins. By soaking the material, its colour was changed to dark yellow. On the other hand, in Slavic culture, the juice was used as a dye ink. Due to the presence of sambunigrin (cyanogenic glycoside), elderberry fruit can be used to obtain a dye with shades from purple to blue. The different colour possibilities are probably a result of the preparation method of the dye mixture and the $\mathrm{pH}$ [38-40].

Chamomile or camomile (Matricaria chamomilla L.) is an annual plant from the Asteraceae family found in Europe, Asia, America and Australia. It is characterized by a stem up to $60 \mathrm{~cm}$ long, branched, with feathery leaves and flowers collected in baskets. In Poland, chamomile can be found on meadows and agricultural wastelands [41]. The raw material is fresh or dried flower baskets - Matricariae flos FP $X I$ (Anthodium Chamomillae), which have anti-inflammatory and anti-allergic properties, soothe the effects of UV rays, and when used internally, also have a relaxing and mildly calming effect. The main anti-inflammatory compounds are the terpenoids: chamazulene and $\alpha$-bisabolol. Apart from them, there are flavonoids, coumarin compounds, mucilages, carotenoids, choline and numerous minerals [42]. Abo- 
ut 120 secondary metabolites have been identified in chamomile, including 28 terpenoids and 36 flavonoids. One of the ways to take advantage of the beneficial properties of this plant is to obtain essential oil. The crucial component is the aforementioned $\alpha$-bisabolol and its oxide azulenes, including chamazulene and acetylene derivatives. It also contains farnesen and $\alpha$-pinene. Other flowers components include several phenolic molecules, mainly flavonoids, like luteolin, as well as apigenin and quercetin [43, 44]. Chamomile is eagerly used in shampoos and hair conditioners. Thanks to its properties, it is perfect for oily and sensitive scalp. It is also used to rinse blonde hair, which was probably due to the fact that chamomile is an excellent yellow dye for dyeing fabrics. The flavonoid luteolin is responsible for the colouring properties of chamomile [45, 46].

\section{SUMMARY}

Chemical colouring allows to dye hair short-term (for the first hair wash), semi-permanent (up to 6-8 washes) and also permanent. However, the last method requires the use of oxidizing substances that alter the structure of the hair and lead to damage to the hair shaft. Moreover, synthetic dyes exhibit a high allergenic potential. An alternative to chemical colouring is colouring with botanical raw materials. The most common natural dyes are naphthoquinones, flavones, anthocyanins and chlorophyll. The plant-based dyeing process involves three main steps - extracting the dyes from a given part of the plant, creating a bond between the dye and the fiber, and ultimately the actual dyeing. The article presents the characteristics of the following plant materials: defenseless lawsonia, hibiscus, rhubarb, elderberry and chamomile. In lawsonia leaves, the presence of a colouring agent was proven - 2-hydroxy-1: 4 naphthoquinone, or lawsone. The hibiscus content responsible for the colour properties is oxalic hibiscus, in rhubarb - chonoids - in elderberry - sambunigrin - and in chamomile - luteolin.

Scientific reports on the safety of plant raw materials in hair dyeing and their beneficial healing and caring properties speak for a wider interest in plant colouring methods.

\section{ACKNOWLEDGMENTS}

The authors would like to thank Mrs. Barbara Butwin for the trichological consultation.

\section{REFERENCES / LITERATURA}

1. Guerra-Tapia A, Gonzalez-Guerra E. Hair Cosmetics: Dyes. Actas Der mosifiliogr. 2014;105:883.

2. Pasco A. Kolorowy zawrót głowy - o sukcesie farb do włosów. Analit. 2018;5:7.

3. Adamski Z, Kaszuba A. Dermatologia dla kosmetologów. Wrocław: Elsevier Urban \& Partner; 2010:147.

4. Matysek-Nawrocka M, Bernat M, Koziarski M. Trychologia kosmetyczna jako metoda diagnozy oraz leczenia wybranych schorzeń skó- ry głowy i włosów. In: Maciag M, Maciag K. Medyczne aspekty kosmetologii i dietetyki. Lublin: TYGIEL; 2018:7-9.

5. Madnani N, Khan K. Hair cosmetics. Symposium-hair disorders. 2013;79: 654-667.

6. Itou T, Ito S, Wakamatsu K. Effects of Aging on Hair Color, Melanosome Morphology, and Melanin Composition in Japanese Females. International Journal of Molecular Sciences. 2019;20:1-2.

7. Sarbak Z, Jachymska-Sarbak B, Sarbak A. Chemia w kosmetyce i kosmetologii. Wrocław: MedPharm Polska; 2013:120.

8. Makuch K, Opasińska K. Wpływ wybranych surowców kosmetycznych na właściwości kosmetyków stosowanych w kondycjonowaniu włosów. Studenckie Zeszyty Naukowe. 2016;1:74-77.

9. Małek E. Charakterystyka budowy i funkcji skóry oraz wtosów. Radom: Instytut Technologii Eksploatacji - Państwowy Instytut Badawczy; 2007:18.

10.Staroń P, Banach M, Kowalski Z. Keratyna - źródła, właściwości, zastosowanie. Chemik. 2011;65:1019-1026.

11. Kieć-Świerczyńska M, Kręcisz B, Świerczyńska-Machura D. Rosnąca rola alergii zawodowej i pozazawodowej na parafenylenodiaminę. $\mathrm{Me}$ dycyna Pracy. 2007;58:131-137.

12. Weser G, Schumacher U, Schoepgens J, Mueller B. Hair dye. United States Patent. 2019:1-2.

13. Polek Ż, Szendzielorz E, Niewęgłowska M et al. Analiza składu dostępnych na polskim rynku farb do włosów pod kątem występowania składników o znanym potencjale uczulającym. Alergologia Polska-Polish Journal of Allergology. 2018;5:121-128.

14. Jin Ahn H, Lee W. An Ultrastuctural Study of Hair Fiber Damage and Restoration Following Treatment With Permanent Hair Dye. Int J Dermatol. 2002;41(2):88-92.

15. Rao M, Sujatha S. Formulation and evaluation of commonly used natural hair colorants. Natural Product Radiance. 2008;7:45-48.

16. Palpu P, Pal M, Shankar Dixit B et al. Herbal dye and process od preparation thereof. United States Patent. 2007:1-7.

17. Packianathan N, Karumbayaran S. Formulation and Evaluation of Herbal Hair Dye: An Ecofriendly Process. Journal of Pharmaceutital Sciences and Research. 2010;2:648-656.

18. Wells K. Colour, health and wellbeing: the hidden qualities and properties of natural dyes. Journal of the International Colour Association. 2013;11:28-36.

19. Gokhale SB, Tatiya AU, Bakliwal SR, Fursule RA. Natural dye yielding plants in India. Natural Product Radiance. 2004;3:228-234.

20. Kapoor VP. Herbal Cosmetics for Skin and Hair care. Natural Product Radiance. 2005;4:306-314.

21. Bechtold T. Natural Colorants in Hair Dyeing. In: Bechtold T, Mussak R. Handbook of Natural Colorants. United Kingdom: John Wiley \& Sons Ltd.; 2009:339-347.

22. Chaudhary G, Goyal S, Poonia P. Lawsonia inermis Linnaeus: A Phytopharmacological Review. IJPSDR. 2010;2:91-98.

23. Mastanaiah J, Prabhavathi NB, Varaprasad B. Invitro Antibacterial activity of Leaf Extracts of Lawsonia inermis. International Journal of PharmTech Research. 2011;3:1045.

24. Abubakar S, Usman AB, Etim V et al. Application of Organic Dyes from Roselle calyx (Hibiscus sabdariffa linn) for Mycological Staining. Indian J Innovations Dev. 2012;1:667.

25. Piątkowska E, Kopeć A, Leszczyńska T. Antocyjany - charakterystyka, występowanie i oddziaływanie na organizm człowieka. Żywność. $\mathrm{Na}$ uka. Technologia. Jakość. 2011;4:24-35.

26. Matławska I. Farmakognozja. Poznań: Uniwersytet Medyczny im. Karola Marcinkowskiego; 2008.

27. Tsai PJ, McIntosh J, Pearce P et al. Anthocyanin and antioxidant capacity in Roselle (Hibiscus sabdariffa L.) extract. Food Research International. 2002;35:351-356.

28. Idham Z, Muhamad II, Sarmidi MR. Degradation Kinetics and Color Stability of Spray-Dried Encapsulated Anthocyanis from Hibiscus Sabdariffa L. Journal of Food Process Engineering. 2012;35:522-542.

29. Adhirajan N, Ravi Kumar T, Shanmugasundaram N, Babu M. In Vivo and in Vitro Evaluation of Hair Growth Potential of Hibiscus Rosa-Sinensis Linn. Journal of Ethnopharmacology. 2003;88:235-239.

30. Pytkowska K, Kruś S, Arct J. Herbal raw materials for grey or bleached hair toning. Warsaw, Poland: Academy of Cosmetics and Health Care; 2008.

31. Vainshelboim A, Vainshelboim T. Henna and Vegetable Dye Based Compositions for Coloring of Human Hair [online]. United States Patent. 
US2010/0313362A1. https://patentimages.storage.googleapis.com/c2/ fb/3d/afdb8697147800/US20100313362A1.pdf. Accessed: 12.09.2021.

32. Azhar M, Anjum N. Revand Chini (Chinese rhubarb): A review on historical and unani classical prospect. International Journal of Unani and Integrative Medicine. 2019;3:11-18.

33. Dyduch J. Bez czarny - charakterystyka biologiczna, wykorzystanie w ziołolecznictwie, kosmetyce i gospodarstwach domowych. Cz. I. Episteme. 2014;25:21-27.

34.Zielińska-Pisklak M, Szeleszczuk Ł, Młodzianka A. Bez czarny (Sambucus nigra) domowy sposób nie tylko na grypę i przeziębienie. Lek w Polsce. 2013;23:1-4.

35.Liszka K, Najgebauer-Lejko D, Tabaszewska M. Owoce czarnego bzu (Sambucus nigra L.) - charakterystyka i możliwości wykorzystania w przemyśle spożywczym. In: Tarko T, Drożdż I, Najgebauer-Lejko D, Duda-Chodak A. Polskie Towarzystwo Technologów Żywności. Kraków: PTTŻ; 2016: 102-109.

36.Doroszko M, Janda K, Jakubczyk K. Właściwości prozdrowotne wybranych owoców krajowych. Kosmos. 2018;67:415-423.

37.El-Amoudy ES, Osman EM. Thermal stability and fastness properties of wool fabric dyed with an eco-friendly natural dye "sambucus nigra" under the effect of different mordants. Applied Chemistry. 2012;44C:7080-7085.
38. Di Tizio A, Łuczaj ŁJ, Quave CL et al. Traditional food and herbal uses of wild plants in the ancient South-Slavic diaspora of Mundimitar/ Montemitro (Southern Italy). Journal of Ethnobiology and Ethnomedicine. 2012;8:1-10.

39. Guarrera PM. Household dyeing plants and traditional uses in some areas of Italy. Journal of Ethnobiology and Ethnomedicine. 2006;2:1-7.

40. Németh É. Colouring (dye) plants. Cultivated Plants, Primarily As Food Sources. 2009;2:353-357.

41. Sumit K, Vivek S, Sujata S, Ashish B. Herbal Cosmetics: Used for Skin and Hair. Inventi Rapid: Cosmeceuticals. 2012;4:1-7.

42. Banasiak E. Zasady pielęgnacji skóry osób narażonych na nikotynę. Kosmetologia Estetyczna. 2015;4(3):243-250.

43. Srivastava JK, Shankar E, Gupta S. Chamomile: A herbal medicine of the past with bright future. Mol Med Report. 2010;3:895-901.

44.Grys A, Kania M, Baraniak J. Rumianek - pospolita roślina zielarska o różnorodnych właściwościach biologicznych i leczniczych. Postępy Fitoterapii. 2014;2:90-93.

45.Grys A, Łowicki Z, Gryszczyńska A et al. Rośliny zielarskie w leczeniu chorób skóry - bezpieczeństwo i zastosowanie. Postępy Fitoterapii. 2011;3:191-196.

46. Chahardoli Z, Vanden Berghe I, Mazzeo R. Twentieth century Iranian carpets: investigation of red dye molecules and study of traditional madder dyeing techniques. Heritage Science. 2019;7:1-17.

otrzymano/received: 20.09.2021 | poprawiono/ corrected:01.10.2021 | zaakceptowano/accepted: 13.10.2021 